\title{
Relationship between Students' Reading Interest and Vocabulary Mastery with Reading Comprehension ability
}

\author{
Fahrurrozi $^{\mathrm{a}}$ \\ a Jakarta State University, Indonesia \\ Corresponde e-mail: ozipasca@gmail.com ${ }^{\mathrm{a}}$
}

\begin{abstract}
$\underline{\text { Abstract }}$
This study aims to determine: (1) the relationship of reading interest with reading comprehension, (2) the relationship of vocabulary mastery with reading comprehension, and (3) the relationship of reading interest and vocabulary mastery to reading comprehension. The method used in this research was descriptive method with a cor-relational technique. The population in this study were all students of class V elementary school 01 Pagi Bendungan Hilir, Central Jakarta, Indonesia amounting to 78 students. The sample were 38 with the sampling technique and taken randomly. The instruments used for data retrieval were through multiple-choice tests for the variables of vocabulary mastery $\left(\mathrm{X}_{2}\right)$ and reading comprehension $(\mathrm{Y})$ and a questionnaire for the variable of reading interest $\left(\mathrm{X}_{1}\right)$. The results of the research showed (1) the research hypothesis is accepted because $\mathrm{r}_{\mathrm{ob}}=$ $0.872>\mathrm{r}_{\text {table }}=0.320$. The coefficient of determination is $(\mathrm{R} 2)=(0.872) 2=0.761$ or $76.1 \%$. This means that the contribution of reading interest $\left(\mathrm{X}_{1}\right)$ amounted to $76.1 \%$ of the reading comprehension $(\mathrm{Y})$. (2) the research hypothesis is accepted because $r_{o b}=0.797>\mathrm{r}$ table $=0.320$. The correlation coefficient between the vocabulary mastery and reading comprehension of 0.797 is significant. (3) The research hypothesis is accepted because $\mathrm{r}_{\mathrm{ob}}=$ $0.873>\mathrm{r}$ table $=0.320$. It can be concluded that the correlation coefficient between the variables of reading interest and vocabulary together with the reading comprehension of 0.873 is significant. The study concluded (1) there is a positive correlation between reading interest with reading comprehension, (2) there is a positive relationship between vocabulary with reading comprehension, and (3) there is a relationship between reading interest and vocabulary mastery to reading comprehension.
\end{abstract}

Key Words: Reading Comprehension, Vocabulary Mastery, Reading Interest

\section{Introduction}

Learning to read in elementary school includes pr-learning to read and learning advanced reading or comprehension. At early stage of learning to read, students learn at first grade, while at second grade students learn advanced reading, students learn at the third grade to sixth. As part of learning to read in elementary school, reading comprehension is a skill to get the message or the information contained in the discourse text so that the reader can understand the meaning to be conveyed by the author through the text .

This is in line with the opinion of Munandar (1992) which says the ability is essentially a power to take action as a result of the nature and exercise. So the ability of a person is not directly but through the process and practice. Of course, the process of improving the ability should be done based on the traits possessed by that person. Lerner in Mulyono Abdurrahman (2003) (Soedarso: 1989) and (Rahim: 2009) said that literacy is the basis for studies master. If a child does not have the ability to read, then the child will have difficulty in studying other fields of study.
Therefore, the ability to read is important for students to learn.

Reading does not only perceive the text, but also to absorb the meaning contained in it, followed by the ability to provide a response or reaction to what is reading which produces understanding. According to Lindgren (1976) and Abbas (2006) reading is an activity to capture the reading of information expressed or implied in the form of literal, inferential, evaluative, and creative of reading comprehension by drawing on the experience of learning to read. Success in reading is influenced by several factors. Ebel in Harras (1999) factors affect the level of reading comprehension depend on (1) students , (2) the family, (3) culture, and (4) the situation of the school. Students must concern toward their learning as well the parents support their learning by giving a guidance home learning which includes learning the cultures. And also the school takes an important role to facilitates a convenience situation and tools for the students.

According to Tarigan (2008) reading comprehension is the kind of reading that aims to understand the reading. Reading 
comprehension means to examine more carefully the reading material so that it can assess the situation, value, function and effect readings. Readers need to use all its capabilities in order to digest the contents of reading. To arrive at the stage of understanding, one must have a work of reason and the power of high abstraction. He can grasp and understand the contents of the texts have been read, lead to its own satisfaction. Therefore, reading comprehension becomes the true purpose of teaching reading. As noted by Candaces (1991) reading comprehension is the ultimate goal of the reading process.

Correlated to the statements, reading comprehension is an activity that is difficult and complex. This is evident from the literacy levels of students in primary schools is still quite low. One of the activities that reveals the lack of reading comprehension is the Program for International Student Assessment (PISA) in 2012. It showed the level of literacy of $64^{\text {th }}$ from 65 countries were participating in the test. The average of reading score result was 395 , while the average score of the OECD was 496 (Kompas, December 5, 2013). In addition to the results of the test PISA above which described the lower level of reading comprehension of students is the result of interviews with teachers at fifth grade elementary school 01 Bendungan Hilir Pagi Jakarta,Indonesia. It was found that from the 78 students of class $\mathrm{V}$, there were 62 students who do not understand the reading discourse text when referring to the material being read and based on the level of knowledge possessed by students should be able to read and understand text well.

Furthermore the ability of students' reading comprehension is low can be affected by various factors, including a low student interest in reading. The purpose of reading will be achieved well and effective if there is an interest and attention of students in reading. Interest is a trait that can be positive and negative settled in a person. Interest in reading is the desire of the individual to do the reading. Reading interests will be able to grow if early accustomed to reading.

Interest is one dimension of the affecting aspect. Interests affect one's thoughts and actions. Interests can be the driving force of someone to act. Hurlock (2005); (Purwanto 1992); and (Sagala 2005) stated that the interest is a source of motivation that drives people to do what they want when they are given the freedom to choose. According to Crow and Crow as quoted by Djaali (2008) said that the interest related to a willingness that encourages a person to confront or deal with people, objects, activities, experiences stimulated by the activity itself.

In other opportunity, Winkel (1995) gave the definition of interest. He defines an interest is a feeling of psychic statement indicating the concentration of attention on an object, because the object is interesting itself. Meanwhile, according to Holland in Djaali (2008) said the interest is the tendency of elevated hearth against something. In other words, the interest must be in accordance with one's own personal. When he considered something that is not appropriate for him, then most likely he will not consider its important or interested in something. Interest does not arise alone, but there is an element of necessity.

Moreover, other factors that contribute in improving students 'reading comprehension is the students' vocabulary mastery. Vocabulary for students of classes V is important. Through the mastery of vocabulary will make it easier for students to understand a variety of reading materials such as textbooks, newspapers, magazines, novels, and other writings. In addition, students do not only know these words from reading or hearing from others, but someday students are also able to productively use the vocabulary that has been known in writing and in oral communication.

Nunan (1998) and Kridalaksana (2001) suggested that the vocabulary or lexicon is the word of wealth owned by a speaker, author or language. In line with this opinion, Keraf (1984) and Soedjito (1992) stated that vocabulary can be distinguished based on two points, namely the angles of quantitative and qualitative. Review of the quantitative angle means that each of the students must master vocabulary as much as possible available in his language. Total vocabulary associated with number concepts and number of controlled vocabularies in turn allows students to form new constructions in forming new concepts. Qualitatively vocabulary is concerning the basic meaning and the meaning of a word or additional meanings of denotation and connotation. Classical structure of words (synonymy, homonym, hiponym and antonym), regarding a word is right and can distinguish it from other similar word spelling, show idiomatic words, pay attention to broad scope of the meaning of each word.

Many things need to be kept in mind that the word that students learn can be successful in accordance with the objectives to be achieved. Teachers, especially Indonesian teacher should 
enrich the vocabulary of learners, by finding the right technique in order to achieve learning objectives. Tarin outlined how the development of vocabulary through: (1) the test, (2) the user context, (3) synonyms, antonyms, and homonyms, (4) the origin of the word, (5) affix, (6) the root of the word, ( 7) style, (8) the expression of proverb, (9) literature, (10) words and spelling, (11) semantics, (12) the use of a dictionary, and (13) wordplay.

At last, the objectives of this research were to know (1) the relationship between reading interest with reading comprehension ability, (2) the relationship between vocabulary mastery and reading comprehension ability, and (3) the relationship between reading interest and vocabulary mastery with the reading comprehension ability. So the hypotheses of this research were (1) there is a relationship between reading interest with reading comprehension ability, (2) there is a relationship between vocabulary mastery and reading comprehension ability, and (3) there is a relationship between reading interest and vocabulary mastery with the reading comprehension ability.

\section{Method}

The method used in this research was descriptive method with a correlation technique. The population in this study were students of class V Elementary school 01 Bendungan Hilir, Central Jakarta, Indonesia. Total population was 78 students. The research sample was done by simple random sampling so that the withdrawal of 38 students was selected as the study sample. The instrument used in this study is the reading interest $\left(\mathrm{X}_{1}\right)$ using questionnaire, vocabulary mastery $\left(\mathrm{X}_{2}\right)$ and reading comprehension (Y) were using multiple choice tests. Data analysis techniques using simple correlation test and multiple correlation test.

\section{Result}

\subsection{Data Description}

The following are descriptions of the data includes the number of samples, mean, median, mode / mode, standard deviation, variance, range, highest value (maximum), and the lowest value (minimum).

\begin{tabular}{|l|l|l|l|}
\hline Statistical & $\begin{array}{c}\text { Reading } \\
\text { Interest } \\
\left(\mathbf{X}_{\mathbf{1}}\right)\end{array}$ & $\begin{array}{c}\text { Vocabulary } \\
\text { Mastery } \\
\left(\mathbf{X}_{\mathbf{2}}\right)\end{array}$ & $\begin{array}{c}\text { Reading } \\
\text { Comprehension } \\
\text { Ability (Y) }\end{array}$ \\
\hline $\begin{array}{l}\text { Numbers } \\
\text { of sample }\end{array}$ & 38 & 38 & 38 \\
\hline $\begin{array}{l}\text { Average } \\
\text { Scores }\end{array}$ & 72.10 & 70.26 & 65.8 \\
\hline median & 73 & 69.8 & 65 \\
\hline mode & 73 & 70 & 64,36 \\
\hline $\begin{array}{l}\text { Standard } \\
\text { Deviation }\end{array}$ & 9.16 & 9.4 & 10.1 \\
\hline $\begin{array}{l}\text { Highest } \\
\text { Scores }\end{array}$ & 91 & 90 & 87 \\
\hline $\begin{array}{l}\text { Lowest } \\
\text { Scores }\end{array}$ & 53 & 50 & 47 \\
\hline
\end{tabular}

Table 1. Statistical Calculation of Variables

$$
\mathrm{X} 1, \mathrm{X} 2 \text {, and } \mathrm{Y}
$$

\subsection{Testing Requirements Analysis}

Testing requirements analysis was conducted to predict whether a homogeneous distribution of data and normal. Testing homogeneity used Bartlet test ,while normality test used chikuadrat .

\subsubsection{Testing Normality}

One-Sample Kolmogorov-Smirnov Test

\begin{tabular}{|l|l|r|}
\hline & & \multicolumn{1}{|c|}{$\begin{array}{c}\text { Reading } \\
\left.\text { Interest } \mathbf{( X}_{\mathbf{1}}\right)\end{array}$} \\
\hline & $\mathrm{N}$ & 38 \\
\hline $\begin{array}{l}\text { Normal } \\
\text { Parameters a,b }\end{array}$ & Mean & 72.2368 \\
\cline { 2 - 3 } & $\begin{array}{l}\text { Std. } \\
\text { Deviation }\end{array}$ & 8.50575 \\
\hline $\begin{array}{l}\text { Most Extreme } \\
\text { Differences }\end{array}$ & Absolute & .141 \\
\cline { 2 - 3 } & Positive & .083 \\
\hline
\end{tabular}

3.2.1.1 Reading Interests Normality

Table 2: The Result of SPPS Output for Normality Test of Reading Interest

Based on Table 2 above, indicates that a test of normality of the data variable of reading interest $\mathrm{K}$-values obtained with Asymp $\mathrm{Z}=$ 0.869. Sig. (2-tailed) $=0.437$. Because Asymp. Sig. (2-tailed) $>0.05$ it can be concluded that the data are normal. 


\subsubsection{Normality of Vocabulary Mastery}

Table 3: The Result of SPSS Output for Normality Test of Vocabulary Mastery

One-Sample Kolmogorov-Smirnov Test

\begin{tabular}{|c|c|c|}
\hline & & $\begin{array}{l}\text { Vocabulary Mastery } \\
\left(\mathrm{X}_{2}\right)\end{array}$ \\
\hline & $\mathrm{N}$ & 38 \\
\hline \multirow{2}{*}{$\begin{array}{l}\text { Normal } \\
\text { Parameters a,b }\end{array}$} & Mean & 70.2632 \\
\hline & \begin{tabular}{|l} 
Std. \\
Deviation
\end{tabular} & 9.40582 \\
\hline \multirow{2}{*}{$\begin{array}{l}\text { Most Extreme } \\
\text { Differences }\end{array}$} & Absolute & .169 \\
\hline & Positive & .169 \\
\hline
\end{tabular}

Based on the table 3 above, indicating that a test of normality of the data obtained mastery of vocabulary K-value $Z=1.042$ with Asymp. Sig. (2-tailed) $=0.228$. Because Asymp. Sig. (2-tailed) $>0.05$ it can be concluded that the data are normal (Pratista; 2002).

\subsubsection{The Normality of Reading}

\section{Comprehension}

Table 4: The result of SPSS output for

One-Sample Kolmogorov-Smirnov Test

\begin{tabular}{|c|c|c|}
\hline & & $\begin{array}{l}\text { Reading } \\
\text { Comprehension } \\
\text { Ability }\end{array}$ \\
\hline & $\mathrm{N}$ & 38 \\
\hline \multirow{2}{*}{$\begin{array}{l}\text { Normal } \\
\text { Parameters } \\
\text { a,,b }\end{array}$} & Mean & 65.1053 \\
\hline & Std. Deviation & 10.88711 \\
\hline \multirow{5}{*}{\begin{tabular}{|l} 
Most \\
Extreme \\
Differences
\end{tabular}} & Absolute & .104 \\
\hline & Positive & .104 \\
\hline & Negative & -.095 \\
\hline & $\begin{array}{l}\text { Kolmogorov-Smirnov } \\
\text { Z }\end{array}$ & .640 \\
\hline & $\begin{array}{l}\text { Asymp. Sig. } \\
\text { (2-tailed) }\end{array}$ & .808 \\
\hline
\end{tabular}

Normality of Reading Comprehension Ability
Based on the table 4, indicates that a test of normality of the data obtained reading comprehension grades $\mathrm{K}-\mathrm{Z}=0.640$ with Asymp. Sig. (2-tailed) $=0.808$. Because Asymp. Sig. (2-tailed) $>0.05$ it can be concluded that the data are normal (Pratista;

Test of Homogeneity of Variances

Reading Comprehension Ability

\begin{tabular}{|c|c|c|c|}
\hline Levene Statistic & $\mathrm{dfl}$ & $\mathrm{df} 2$ & Sig. \\
\hline 2.805 & 8 & 24 & .124 \\
\hline
\end{tabular}

\subsubsection{Testing Homogeneity}

Homogeneity test on test data using Levene Test.

\subsubsection{Homogeneity Data of Reading} Interests

Table 5: The Result of SPSS Output for

\section{Test of Homogeneity of Variances}

Reading Interest

\begin{tabular}{|r|r|c|c|}
\hline Levene Statistic & df1 & \multicolumn{1}{c|}{ df2 } & \multicolumn{1}{c|}{ Sig. } \\
\hline 1.814 & 8 & 24 & .124 \\
\hline
\end{tabular}

Based on Table 5, it turns $0,05 \alpha=$ less or equal to the value of sig. $=0.124$, then so Ho rejected and $\mathrm{H} 1$ accepted meaning of the students' reading interest data were homogeneous (similar).

\subsubsection{Homogeneity Data of Vocabulary Mastery}

Table 6: The result of SPSS Output for Homogeneity Test of Vocabulary Mastery

Test of Homogeneity of Variances

Vocabulary Mastery 


\begin{tabular}{|r|r|r|r|}
\hline $\begin{array}{c}\text { Levene } \\
\text { Statistic }\end{array}$ & df1 & df2 & Sig. \\
\hline 2.079 & 10 & 25 & .067 \\
\hline
\end{tabular}

Based on the table 6 , it turns $0,05 \alpha=$ is less than or equal to the value of sig. $=0.067$, then so Ho rejected and $\mathrm{H} 1$ accepted meaning of the vocabulary data were homo gen (similar).

\subsubsection{Homogenity Data of Reading}

\section{Comprehension Ability}

Table 7: The Result of SPSS Output for Homogeneity Test of Reading Comprehension

Based on the table 8 , was $\alpha=0.05$ is less than or equal to the value sig. $=0.124$, then the Ho accepted and $\mathrm{H} 1$ rejected it means that the data of reading comprehension was homogeneous (similar)

\subsection{Research Hypothesis Testing}

The hypothesis to be tested empirically in this research were three: (1) There was a significant interest in reading with reading comprehension of Elementary School fifth grade students 01 Bendungan Hilir, Central Jakarta, Indonesia ; (2) There was a significant correlation between vocabulary to reading comprehension of Elementary School fifth grade students (3) There is a significant relationship between reading interest and vocabulary mastery to reading comprehension students of fifth grade 01 Bendungan Hilir, Central Jakarta, Indonesia.

3.3.1 The relationship between reading interest and reading comprehension

The first hypothesis stated that there is a significant correlation between reading interest $\left(\mathrm{X}_{1}\right)$ with reading comprehension $(\mathrm{Y})$. Simple correlation analysis was conducted to determine the strength of the relationship between the predictor variables with the response variable. The strength of the relationship between reading interest $\left(\mathrm{X}_{1}\right)$ with reading comprehension $(\mathrm{Y})$ is indicated by the correlation coefficient $\mathrm{r}=0.872$. The correlation coefficient significance test are listed in the following table.

\begin{tabular}{|c|c|c|c|}
\hline Correlation & $\begin{array}{l}\text { Correlation } \\
\text { Coefficient }\end{array}$ & $\begin{array}{l}\text { Determination } \\
\text { Coefficient }\end{array}$ & Significance \\
\hline $\mathrm{X}_{1 \text { and }} \mathrm{Y}$ & 0,872 & 0,761 & 0,000 \\
\hline
\end{tabular}

Table 8: Simple Correlation Coefficient

\begin{tabular}{|c|c|c|c|}
\hline Correlation & $\begin{array}{c}\text { Correlation } \\
\text { Coefficient }\end{array}$ & $\begin{array}{c}\text { Determination } \\
\text { Coefficient }\end{array}$ & Significance \\
\hline $\mathrm{X}_{2 \text { and }} \mathrm{Y}$ & 0,797 & 0,635 & 0,000 \\
\hline
\end{tabular}

Significance Test between $\mathrm{X}_{1}$ with $\mathrm{Y}$

Significant correlation coefficient test results showed that the null hypothesis is rejected because $\mathrm{r}_{\mathrm{ob}}=0.872>\mathrm{r}_{\text {table }}=0.320$. It can be concluded that the coefficient of correlation between reading interest and reading comprehension of 0.872 is highly significant. Thus, there is a positive relationship between reading interest $\left(\mathrm{X}_{1}\right)$ and reading comprehension $(\mathrm{Y})$. It can be said that the higher interest in reading, the higher the students' reading comprehension.

\subsubsection{The relationship between vocabulary mastery and reading comprehension}

The second hypothesis states that there is a significant relationship between vocabulary mastery $\left(\mathrm{X}_{2}\right)$ with reading comprehension $(\mathrm{Y})$. Correlation analysis was conducted to determine the strength of the relationship between the predictor variables with the response variable. The strength of the relationship between vocabulary mastery $\left(\mathrm{X}_{2}\right)$ with reading comprehension $(\mathrm{Y})$ is indicated by the correlation coefficient $r=0.797$. The correlation coefficient significance test are listed in the following table.

Table 9

\section{Table 9: Simple Correlation Coefficient}

\section{Significance Test between $\mathrm{X}_{2}$ with $\mathrm{Y}$}

Significant correlation coefficient test results showed that the null hypothesis is rejected because $r_{\text {obtained }}=0.797>r_{\text {table }}=0.320$. It can be concluded that the correlation coefficient vocabulary mastery to reading comprehension of 0.797 is significant. Thus, there is a positive relationship between vocabulary mastery $\left(\mathrm{X}_{2}\right)$ and reading comprehension (Y).

It can be said that the higher the vocabulary, the higher reading ability of students. The coefficient of determination was $(\mathrm{R} 2)=(0.797)$ $2=0.635$ or $63.5 \%$. These data proved that the contribution of vocabulary to read is something about the ability of understanding by $63.5 \%$. That is, reading comprehension can 
be improved through increasing mastery of the vocabulary in students as it has a contribution of $63.5 \%$

\subsubsection{Relationship of reading interests and vocabulary mastery with reading comprehension ability}

The third hypothesis mentioned there is a significant relationship between interest in reading $\left(\mathrm{X}_{1}\right)$ and vocabulary mastery $\left(\mathrm{X}_{2}\right)$ with reading comprehension $(\mathrm{Y})$. Multiple correlation analysis was conducted to determine the strength of the relationship between the predictor variables with the response variable. The strength of the relationship between reading interest $\left(\mathrm{X}_{1}\right)$ and vocabulary mastery $\left(\mathrm{X}_{2}\right)$ together with reading comprehension $(\mathrm{Y})$ is indicated by a 1.2 correlation coefficient $r=0.873$. The correlation coefficient significance test are listed in the table below.

Table 10: Multiple Correlation Coefficient Significance Test between $X_{1}, X_{2}$, and $Y$

\begin{tabular}{|c|c|c|c|}
\hline Correlation & $\begin{array}{c}\text { Correlation } \\
\text { Coefficient }\end{array}$ & $\begin{array}{c}\text { Determination } \\
\text { Coefficient }\end{array}$ & Significance \\
\hline $\mathrm{X}_{1}, \mathrm{X}_{2, \text { and }} \mathrm{Y}$ & 0,873 & 0,762 & 0,000 \\
\hline
\end{tabular}

Significant correlation coefficient test results showed that the null hypothesis is rejected because $r_{o b}=0.873>r_{\text {table }}=0.320$. It can be concluded that the correlation coefficient between the variables of reading interest and vocabulary mastery together with the reading comprehension of 0.873 is significant. Thus, there is a positive relationship between reading interest $\left(\mathrm{X}_{1}\right)$ and vocabulary mastery $\left(\mathrm{X}_{2}\right)$ with reading comprehension $(\mathrm{Y})$.

It can be said that the higher of students' reading interest and vocabulary mastery, the higher the students' reading comprehension. Determination coefficients $(\mathrm{r} 2)=(0.873)=$ 0.762 or $76.2 \%$. These data proved that the contribution of reading interest and vocabulary mastery together on the ability to read comprehension was $76.2 \%$. This suggests that other factors which affect reading comprehension (Y) Elementary School fifth grade students 01 Bendungan Hilir, Central Jakarta, Indonesia was $23.8 \%$.

\subsection{Discussion of Research Results}

The results showed that all of this hypothesis can be proven. The data in the study support the statement on the research hypothesis. The first hypothesis states that there is a significant relationship between interest in reading with reading comprehension Elementary School fifth grade students 01 Bendungan Hilir, Jakarta Pusat, Indonesia. The second hypothesis states that there is a significant correlation between vocabulary to reading comprehension Elementary School fifth grade students 01 Bendungan Hilir, Jakarta Pusat, Indonesia. While the third hypothesis mentioned that there is a significant relationship between reading and vocabulary to reading comprehension Elementary School fifth grade students 01 Bendungan Hilir, Jakarta Pusat, Indonesia.

Based on the calculation results of hypothesis testing, the hypothesis of the first, second, and third turned out everything is significant. This means that this study has successfully demonstrated the relationship between reading interest $\left(\mathrm{X}_{1}\right)$ with reading comprehension $(\mathrm{Y})$, vocabulary mastery $\left(\mathrm{X}_{2}\right)$ with reading comprehension (Y). In addition, this research has also shown that reading interest $\left(\mathrm{X}_{1}\right)$ and vocabulary $\left(\mathrm{X}_{2}\right)$ have a very positive relationship with reading comprehension (Y).

There is a positive and significant relationship between vocabulary mastery and reading comprehension. This suggests that if the vocabulary is increased then reading comprehension does,too. The test results showed the correlation coefficient was significant that the research hypothesis is accepted because $r_{\mathrm{ob}}=0.797>\mathrm{r}_{\text {table }}=0.320$. The correlation coefficient between the vocabulary to reading comprehension of 0.797 is significant. Thus, there is a positive relationship between vocabulary $\left(\mathrm{X}_{2}\right)$ and reading comprehension $(\mathrm{Y})$. It can be said that the higher the vocabulary, the higher students' reading ability. The coefficient of determination $(\mathrm{R} 2)=(0.797)=0.635$ or $63.5 \%$. These data proved that the contribution of vocabulary to read something about the ability of understanding by $63.5 \%$. That is, reading comprehension can be improved through increasing mastery of the vocabulary in students as it has a contribution of $63.5 \%$.

There is a positive and significant relationship between reading interest and vocabulary mastery to reading comprehension. This shows that if reading interest and vocabulary mastery jointly enhanced the reading comprehension as well. The test results showed the correlation coefficient was significant that the research 
hypothesis is accepted because $r_{o b}=0.873>r$ table $=0.320$. It can be concluded that the correlation coefficient between the variables of reading interest and vocabulary mastery together with the reading comprehension of 0.873 is significant. Thus, there is a positive relationship between reading interest $\left(\mathrm{X}_{1}\right)$ and vocabulary mastery $\left(\mathrm{X}_{2}\right)$ and reading comprehension (Y). It can be said that the higher reading interest and vocabulary mastery of students, the higher the students' reading comprehension is. Coefficient determination is $(\mathrm{r} 2)=(0.873)=0.762$ or $76.2 \%$. These data proved that the contribution of reading interest and vocabulary mastery together have correlation with reading comprehension of $76.2 \%$. This suggests that other factors which affect reading comprehension (Y) class $\mathrm{V}$ students of primary school 01 Bendungan Hilir, Central Jakarta, Indonesia is $23.8 \%$.

\section{Acknowledgment}

Researchers give their first big thanks to English teachers and second salutation to the fifth grade students of Elementary School 01 Bendungan Hilir, Central Jakarta, Indonesia.

\section{References}

[1] Abbas, Saleh. (2006). Pembelajaran Bahasa Indonesia yang Efektif di Sekolah Dasar. Jakarta: Depdiknas.

[2] Abdurrrahman, Mulyono, (2003) Pendidikan Bagi Anak Bekesulitan Belajar. Jakarta: PT Rineka Cipta,

[3] Candaces, Bos. (1991) Strategis for Teaching Student with Learning and Behavior Problems. Massa Chusetts: Ally and Bacon.

[4] Djaali. (2008) Psikologi Pendidikan. Jakarta: Bumi Aksara.

[5] Harras, A. Kholid. (1997). Membaca 1. Jakarta: Universitas Terbuka.

[6] Hurlock, Elizabeth B. (2005). Perkembangan Anak Jilid 2 Edisi Keenam. Terjemahan Meitasari Tjandrasa. Jakarta: Erlangga.

[7] Keraf, Gorys. (1994). Komposisi. Flores: Nusa Indah.

[8] Kridalaksana, Harimurti.(2008). Kamus Linguistik. Jakarta: PT Gramedia Pustaka Utama.

[9] Munandar, S.C. Utami, (1992). Mengembangkan Bakat dan Kreativitas Anak Sekolah. Jakarta: Grasindo.
[10] Rahim, Farida, (2008). Pengajaran Membaca di Sekolah Dasar. Jakarta: Bumi Aksara.

[11] Tarigan, Henry Guntur. (2008). Membaca Sebagai Suatu Keterampilan Berbahasa. Bandung: Angkasa Bandung.

[12] Tarigan. Henry Guntur. (1993). Pengajaran Kosakata. Bandung: Angkasa.

[13] Winkel,W.S. (2004). Bimbingan dan Konseling di Institut Pendidikan. Jakarta: Grasindo.

[14] Nunan, David. (1998).Language Teaching Methodology. New York: Prentice Hall.

[15] Soedjito. (1992). Kosakata Bahasa Indonesia. Jakarta:PT.Gramedia Pustaka.

[16] Soedarso. (1989). Sistem Membaca Cepat dan Efektif. Jakarta: PT Gramedia.

[17] Lindgren, Henry Clay and John Wiley. (1976). Educational Psychology in The Classroom. New York.

[18] Purwanto, Ngalim. (1992).Psikologi Pendidikan. Bandung: Remaja Rosda Karya.

[19] Syaiful, Sagala. (2005). Konsep dan Makna Pembelajaran. Bandung: Alfabeta.

[20] Sardiman A. M. (1996). Interaksi dan Motivasi Belajar Mengajar. Jakarta: Raja Grafindo Persada. 